\title{
PERCEPTIONS OF TAXATION: A COMPARATIVE STUDY OF DIFFERENT POPULATION GROUPS IN SOUTH AFRICA
}

\author{
BY
}

RUANDA OBERHOLZER

SUBMITTED IN FULFILMENT OF THE REQUIREMENTS FOR THE DEGREE

\section{DOCTOR COMMERCII}

\section{(ACCOUNTING SCIENCES WITH SPECIALISATION IN TAXATION)}

\author{
IN THE
}

FACULTY OF ECONOMIC AND MANAGEMENT SCIENCES

AT THE

UNIVERSITY OF PRETORIA

PROMOTER: Prof E M Stack

CO-PROMOTER: Prof R S Rensburg 


\section{ACKNOWLEDGEMENTS}

"There is no more noble occupation in the world than to assist another human being - to help someone succeed." - Alan Loy McGinnis

I would like to extend my appreciation to the following exceptional individuals:

- Prof Lilla Stack, my promoter, for her guidance and encouragement throughout this study. Without her expert contribution and confidence in my ability, this research would not have been possible.

- Prof Ronel Rensburg, my co-promoter, for her valuable input and inspiration.

- Bianca Nothnagel, my research assistant, for many hours of hard work. Your professional assistance and personal friendship is highly appreciated.

- Hendriëtte Jansen van Vuuren, from the academic information services at the University of Pretoria, for her ardent labour in securing reference material.

- Jaqui Sommerville and Loina Bodenstein, from the Department of Statistics, for their expert advice and constant willingness to assist at all times.

- Prof Mauritz Oberholzer, Bev Streng, Priscilla Nothnagel and Gene van Blommestein for their thoroughness and effort in proof reading and editing the document.

- Colleagues in the Department of Taxation and in the Faculty of Economic and Management Science for their support and encouragement to persevere.

- The National Research Foundation (NRF) for financial assistance.

- My parents, whose contribution to my success stretches over many years of caring, encouragement, sacrifice and love.

- Family and friends, whose prayers, support and encouragement carried me through times of despondency and threatening despair.

- My husband, Francois and our daughter, Emma, for their positive support and patience.

"Praise the Lord, all you nations; extol him, all you peoples. For great is His love towards us, and the faithfulness of the Lord endures for ever." - Psalm 117 (NIV) 


\section{ABSTRACT}

In South Africa, there is a significant gap between the amount of tax that is theoretically collectable from economically active persons and that which is actually collected (commonly known as the "tax gap"). Non-compliance by taxpayers is one of the main causes of the tax gap. It has been established that one of the main factors leading to non-compliance, is the attitudes and perceptions of people.

Although the perceptions of previously disadvantaged groups in South Africa regarding taxation have been researched, this study extends prior research by investigating and comparing taxpayers' perceptions amongst the four major South African population groups (that is, Black/African, Indian, Coloured and White). This is the main objective of this thesis.

This study specifically aimed to determine South African taxpayers' perceptions regarding general tax-related, tax evasion and tax compliance issues. A number of demographic, economic or other factors that might influence respondents' perceptions regarding these issues were also investigated.

The significance of this study is emphasised, in that it builds upon previous research, utilising insights from several disciplines and various theoretical perspectives.

The data for this study was collected from a sample of 260 South African taxpayers by means of face-to-face interviews, based on a questionnaire, compiled from an extensive literature review. The scope of the study was limited as it focused only on natural taxpayers within the Tshwane metropolitan area (which includes Pretoria, the capital city of South Africa) in Gauteng, as the purpose was not to generalise conclusions to the entire South African population. A further limitation of the study was that it focused on natural persons only; corporate taxpayers were excluded. Future research could extend this study by verifying the findings in other areas, amongst other population groups and corporate taxpayers. 
This research concluded that tax compliance may depend upon several factors, other than deterrence, and that the perceptions of South African taxpayers are likely to be influenced by these factors. One of the main recommendations of the study is the need for comprehensive, widely based communication and education of taxpayers and potential taxpayers by the South African Revenue Services.

Keywords:

South African taxpayers

Population groups

Perceptions of taxation

Taxpayer education 


\section{TABLE OF CONTENTS}

CHAPTER 1: INTRODUCTION TO THE STUDY 1

$1.1 \quad$ INTRODUCTION AND BACKGROUND TO THE STUDY .......................................

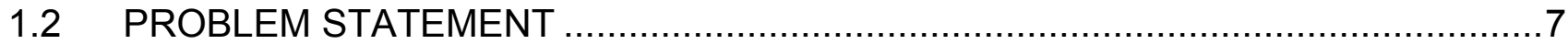

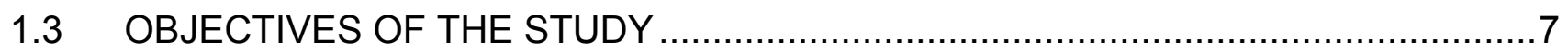

1.4 IMPORTANCE AND BENEFITS OF THE STUDY ….........................................

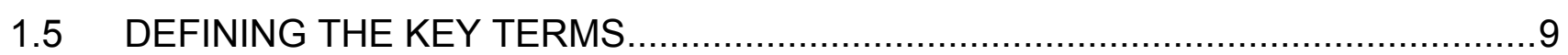

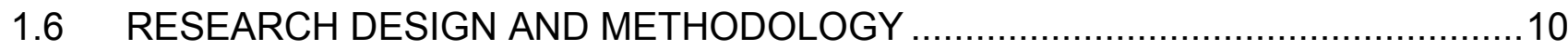

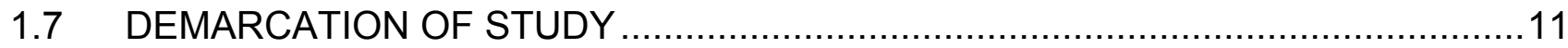

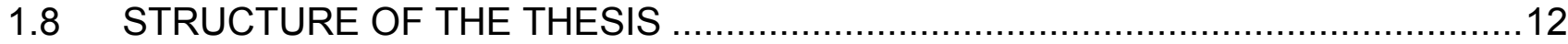

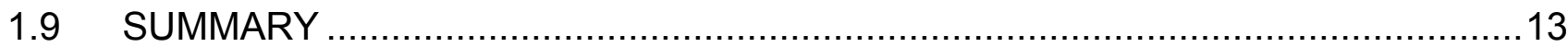

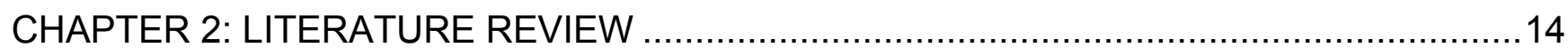

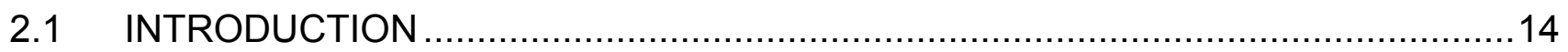

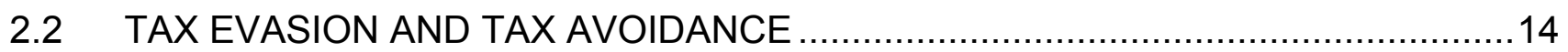

2.3 WHY DO PEOPLE EVADE TAXES? - AN ECONOMIST'S VIEWPOINT ................16

2.4 WHY DO PEOPLE EVADE TAXES? - A SOCIAL PSYCHOLOGICAL

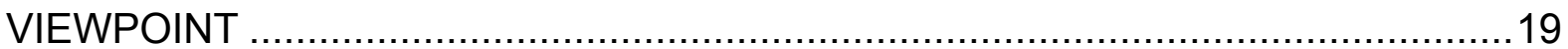

2.5 PREVIOUS EMPIRICAL RESEARCH PERFORMED ON TAX-RELATED

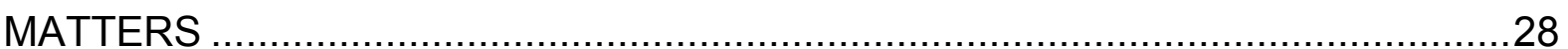

2.6 PREVIOUS RESEARCH PERFORMED IN RELATION TO TAXPAYERS IN

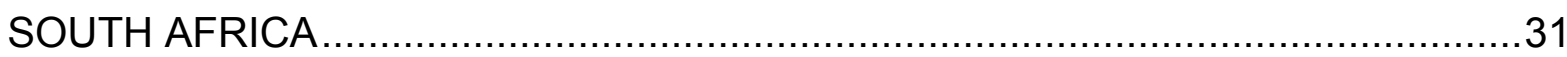

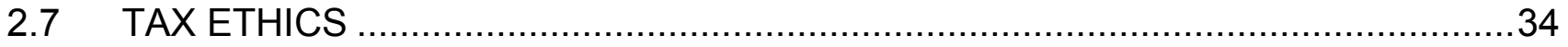

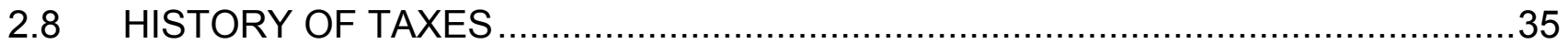

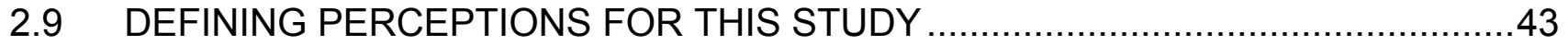

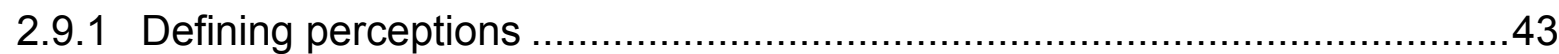

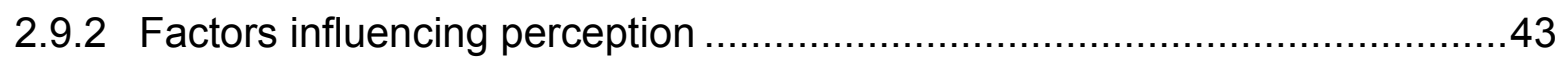

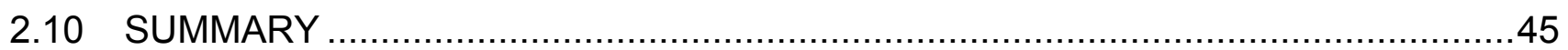

CHAPTER 3: RESEARCH DESIGN AND METHODOLOGY …....................................4

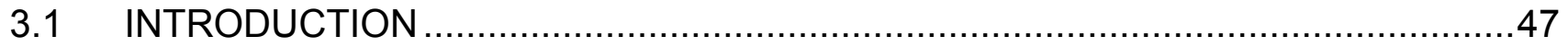

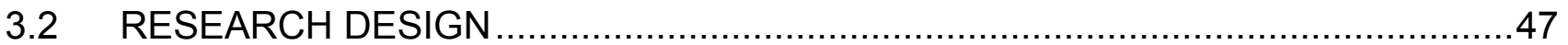

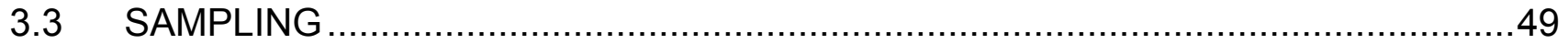

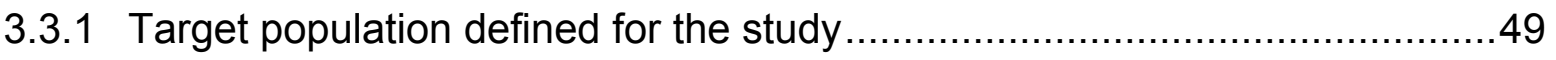


3.3.2 Sample size and sampling method employed 49

3.4 DATA COLLECTION 53

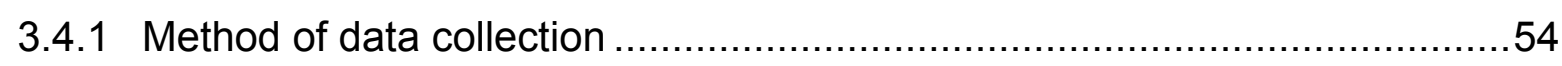

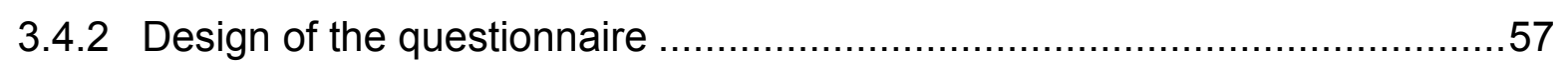

3.4.3 Pre-testing the questionnaire and period in which fieldwork was

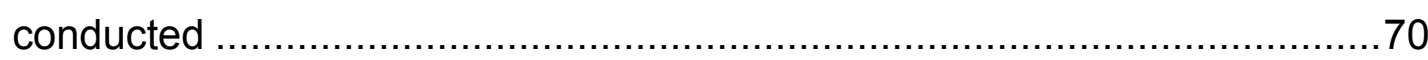

3.4.4 Realised sample size and number of usable questionnaires ....................71

3.5 PREPARATION, ANALYSIS AND INTERPRETATION OF DATA .......................72

3.5.1 Editing and coding the data..................................................... 72

3.5.2 Method of analysis and statistical techniques ................................... 74

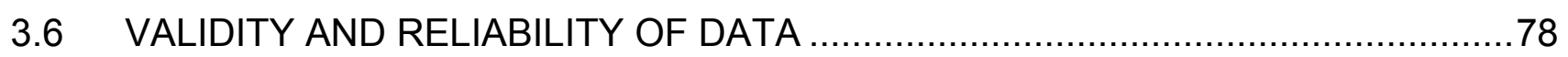

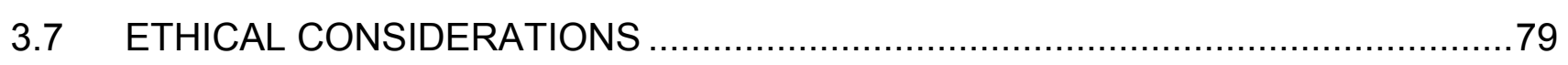

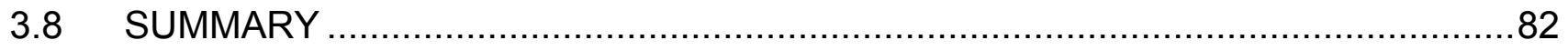

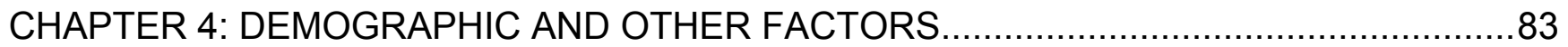

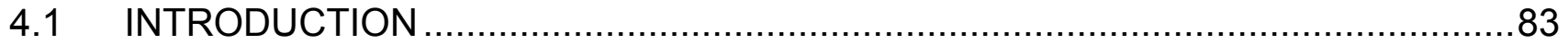

4.2 REPRESENTATIVITY OF THE SAMPLE $\ldots \ldots \ldots \ldots \ldots \ldots \ldots \ldots \ldots \ldots \ldots \ldots \ldots \ldots \ldots \ldots . . . \ldots 3$

4.2.1 Demographic profile of respondents .............................................. 84

4.3 ECONOMIC CIRCUMSTANCES OF THE RESPONDENTS $\ldots \ldots \ldots \ldots \ldots \ldots \ldots \ldots \ldots \ldots . . \ldots 2$

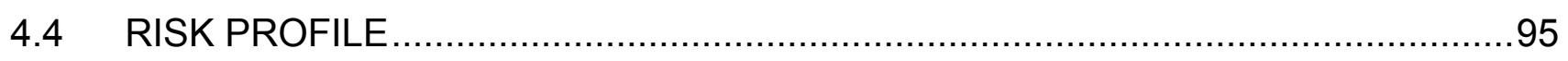

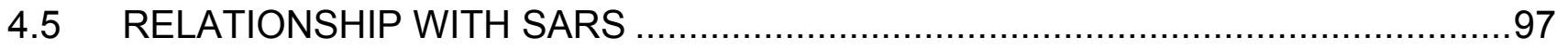

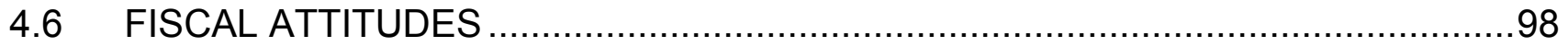

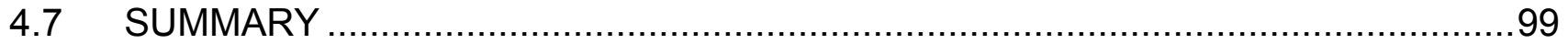

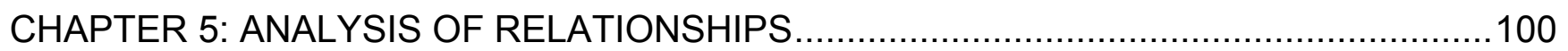

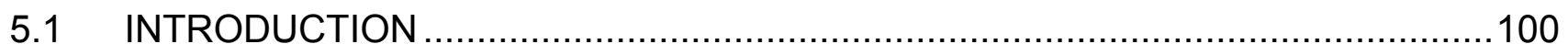

5.2 PERCEPTIONS OF GENERAL TAX-RELATED ISSUES ................................101

5.2.1 Statement 1: "A large proportion of taxes is used by the government for meaningless purposes" ............................................................... 105

5.2.2 Statement 2: "It is unfair to pay tax" .............................................. 111

5.2.3 Statement 3: "Income tax rates must be reduced" ................................115

5.2.4 Statement 4: "The VAT rate must be reduced" ................................ 120

5.2.5 Statement 5: "The income tax rate (\%) should be the same regardless of the amount of income earned (i.e. everybody pays income tax using the same percentage irrespective of the amount you earn)" ........................122

5.2.6 Statement 6: "I do not know why I have to pay tax" ................................ 128 
5.2.7 Statement 7: "Waste and corruption in government is high"

5.2.8 Statement 8: "Rich people should pay tax at a higher rate"

5.2.9 Statement 9: "Tax is very complicated - I do not know how to calculate my own tax liability"

5.2.10 Statement 10: "The amount of tax I have to pay is reasonable considering the benefits received"

5.2.11 Statement 11: "The government does not provide enough information about how they use taxpayers' money".....

5.3 PERCEPTIONS OF TAX EVASION

5.3.1 Individual demographic, economic or other factors influencing respondents' attitudes towards tax evasion

5.3.2 Relationship between respondents' perceptions regarding a specific taxrelated statement and tax evasion

5.4 PERCEPTIONS OF TAX COMPLIANCE

5.4.1 Individual demographic, economic or other factors influencing respondents' attitudes towards tax compliance.

5.4.2 Relationship between respondents' perceptions regarding a specific taxrelated statement and tax compliance.

5.4.3 Relationship between respondents' perceptions regarding specific statements that concern tax evasion (excluding those statements relating to penalties related to tax evasion) and tax compliance.

5.5 PERCEPTIONS OF PENALTIES RELATED TO TAX EVASION

5.5.1 Respondents' perceptions regarding the appropriateness of penalties related to tax-related offences.

5.5.2 Relationship between respondents' perceptions regarding the severity of penalties for tax evasion and tax evasion and tax compliance. 201

5.5.3 Relationship between respondents' perceptions regarding specific statements that concern penalties associated with tax evasion and tax compliance 203

5.6 SUMMARY 205

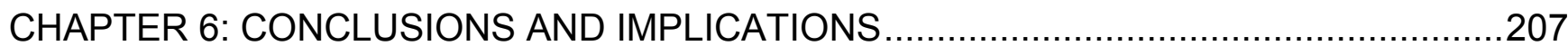

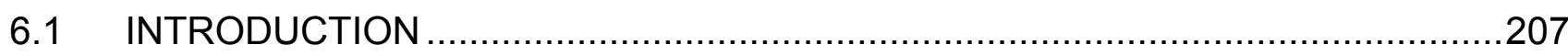

6.2 STRATEGIES FOR GOVERNMENT TO ADDRESS TAX EVASION ....................207

6.3 RESPONDENTS' COMMENTS REGARDING TAXATION IN SOUTH AFRICA ....211 
6.3.1 A need for information regarding tax. 211

6.3.2 Specific comments concerning tax issues............................................214

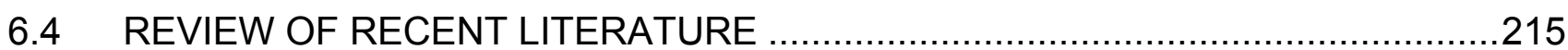

6.5 SUMMARY OF FINDINGS AND CONCLUSIONS OF THE RESEARCH .............216

6.5.1 Perceptions about general tax-related issues amongst South African taxpayers

6.5.2 Demographic, economic or other factors that might influence taxpayers' attitudes with regard to general tax-related issues

6.5.3 Perceptions about tax evasion and tax compliance statements amongst South African taxpayers

6.5.4Relationship between respondents' views regarding specific tax-related statements and their attitudes towards tax evasion and tax compliance ......224

6.5.5 Relationship between taxpayers' views concerning a specific tax evasion statement and their attitudes towards tax compliance

6.5.6 Perceptions about tax penalties

6.5.7 Perceptions about taxation amongst the various South African population groups

6.5.8 Findings from the present research versus findings from previous research 229

6.5.9 Results of the open-ended question 243

6.5.10 Shortcomings of the study 244

6.5.11 Concluding comment regarding the overall findings of this study 245

6.6 LIMITATIONS TO THE STUDY AND RECOMMENDATIONS FOR FUTURE RESEARCH 245

6.7 SUMMARY 246 


\section{APPENDICES}

APPENDIX A: $\quad$ AREAS SURVEYED IN THE TSHWANE METROPOLITAN AREA AND NUMBER OF RESPONDENTS IN EACH POPULATION GROUP 262

APPENDIX B: $\quad$ FINAL QUESTIONNAIRE USED TO COLLECT THE DATA FOR THE STUDY 264

APPENDIX C: RESPONDENTS' COMMENTS CONCERNING EXPOSURE TO TAX INFORMATION IN SOUTH AFRICA ANALYSED USING DIFFERENT THEMES. 273

APPENDIX D: RESPONDENTS' COMMENTS CONCERNING EXPOSURE TO TAX INFORMATION IN SOUTH AFRICA 275

APPENDIX E: $\quad$ SPECIFIC POSITIVE COMMENTS FROM RESPONDENTS REGARDING TAXATION IN SOUTH AFRICA 278

APPENDIX F: $\quad$ SPECIFIC NEGATIVE COMMENTS FROM RESPONDENTS REGARDING TAXATION IN SOUTH AFRICA ANALYSED IN DIFFERENT THEMES.

APPENDIX G: SPECIFIC NEGATIVE COMMENTS FROM RESPONDENTS REGARDING TAXATION IN SOUTH AFRICA 


\section{LIST OF FIGURES}

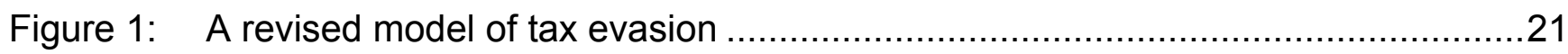

Figure 2: Factors influencing a taxpayer's compliance decision................................27

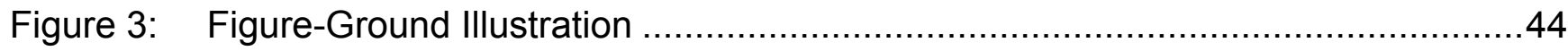

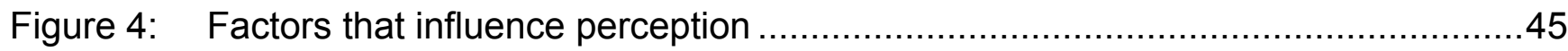

Figure 5: Example of a Kish Grid used to select household members ...........................53

Figure 6: Gender composition of the population for the study ................................... 85

Figure 7: Distribution of population groups included in the study ..............................86

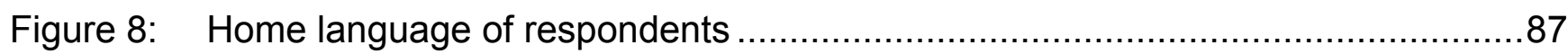

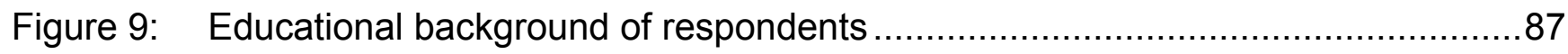

Figure 10: Level of education of South Africans amongst those aged 20 years and older

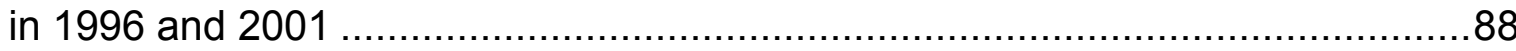

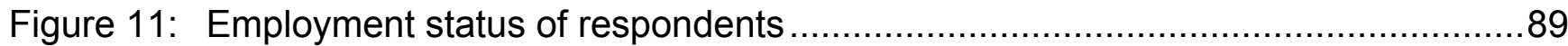

Figure 12: Income per month before deductions of respondents ..................................90

Figure 13: Income per month amongst the employed aged 15-65 years in South Africa in 1996

Figure 14: Income per month amongst the employed aged 15-65 years in South Africa in

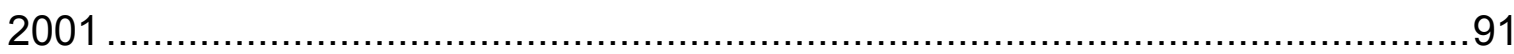

Figure 15: Type of dwelling in which respondents reside ..........................................92

Figure 16: Frequency of visits to state-funded medical facilities ..................................94

Figure 17: Number of persons living within a household ...........................................94

Figure 18: How respondents would invest R10 000 that they had won or inherited .............96

Figure 19: Percentage of respondents who like to/do not like to take risks .......................96

Figure 20: Percentage of respondents who indicated that the penalty for tax evasion is too severe/not too severe ......................................................................201 


\section{LIST OF TABLES}

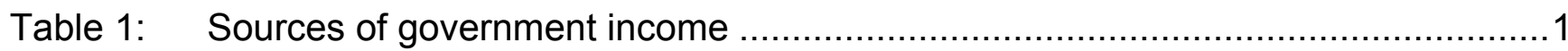

Table 2: Number of respondents intended to be surveyed in each population group ........51

Table 3: Support from the literature for the inclusion of specific statements that relate to general tax issues

Table 4: Support from the literature for including specific statements that relate to tax evasion

Table 5: Support from the literature for including specific statements that relate to tax compliance and respondents' risk profile

Table 6: Variables initially used in the questionnaire and new variables formed.................74

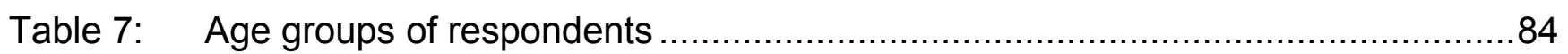

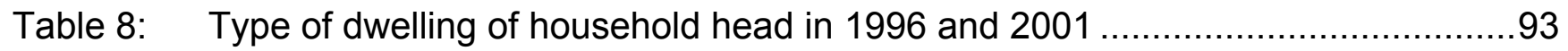

Table 9: Findings related to statements that concern respondents' experience with SARS officials

Table 10: Responses regarding respondents' attitudes towards general tax-related statements

Table 11: Relationship between respondents' demographic, economic or other factors and their attitudes towards general tax-related statements.

Table 12: Responses of age groups regarding the statement: "A large proportion of taxes is used by the government for meaningless purposes".

Table 13: Responses of population groups regarding the statement: "A large proportion of taxes is used by the government for meaningless purposes"

Table 14: Responses concerning number of people living within a household and respondents' attitudes towards the statement: "A large proportion of taxes is used by the government for meaningless purposes"

Table 15: Responses concerning respondents' support for the current government and their attitudes towards the statement: "A large proportion of taxes is used by the government for meaningless purposes"

Table 16: Responses concerning respondents' views about the future of South Africa and their attitudes towards the statement: "A large proportion of taxes is used by the government for meaningless purposes". 
Table 17: Responses of population groups regarding the statement: "It is unfair to pay tax"

Table 18: Responses concerning respondents' support for the current government and their attitudes towards the statement: "It is unfair to pay tax"

Table 19: Responses concerning respondents' views about the future of South Africa and their attitudes towards the statement: "It is unfair to pay tax"

Table 20: Responses of population groups regarding the statement: "Income tax rates must be reduced"

Table 21: Responses concerning respondents' support for the current government and their attitudes towards the statement: "Income tax rates must be reduced" .......118

Table 22: Responses concerning respondents' views about the future of South Africa and their attitudes towards the statement: "Income tax rates must be reduced" 119

Table 23: Responses concerning respondents' support for the current government and their attitudes towards the statement: "The VAT rate must be reduced"

Table 24: Responses of population groups regarding the statement: "The income tax rate $(\%)$ should be the same regardless of the amount of income earned (i.e. everybody pays income tax using the same percentage irrespective of the amount you earn)"

Table 25: Responses of language groups regarding the statement: "The income tax rate (\%) should be the same regardless of the amount of income earned (i.e. everybody pays income tax using the same percentage irrespective of the amount you earn)"

Table 26: Responses concerning respondents' support for the current government and their attitudes towards the statement: "The income tax rate (\%) should be the same regardless of the amount of income earned (i.e. everybody pays income tax using the same percentage irrespective of the amount you earn)".

Table 27: Responses concerning respondents' views about the future of South Africa and their attitudes towards the statement: "The income tax rate (\%) should be the same regardless of the amount of income earned (i.e. everybody pays income tax using the same percentage irrespective of the amount you earn)" ..128

Table 28: Responses of age groups regarding the statement: "I do not know why I have to pay tax"

Table 29: Responses of population groups regarding the statement: "I do not know why I have to pay tax" 
Table 30: Responses of language groups regarding the statement: "I do not know why I have to pay tax"

Table 31: Responses concerning respondents' support for the current government and their attitudes towards the statement: "I do not know why I have to pay tax" .....133

Table 32: Responses concerning respondents' views about the future of South Africa and their attitudes towards the statement: "I do not know why I have to pay tax"

Table 33: Responses of population groups regarding the statement: "Rich people should pay tax at a higher rate"

Table 34: Responses concerning respondents' views about the future of South Africa and their attitudes towards the statement: "Rich people should pay tax at a higher rate".

Table 35: Responses of population groups regarding the statement: "Tax is very complicated - I do not know how to calculate my own tax liability"

Table 36: Responses of language groups regarding the statement: "Tax is very complicated - I do not know how to calculate my own tax liability"

Table 37: Responses concerning the number of people living within respondents' households and their attitudes towards the statement: "Tax is very complicated - I do not know how to calculate my own tax liability"

Table 38: Responses concerning respondents' support for the current government and their attitudes towards the statement: "Tax is very complicated - I do not know how to calculate my own tax liability"

Table 39: Responses of age groups regarding the statement: "The amount of tax I have to pay is reasonable considering the benefits received".

Table 40: Responses of population groups regarding the statement: "The amount of tax I have to pay is reasonable considering the benefits received".

Table 41: Responses of language groups regarding the statement: "The amount of tax I have to pay is reasonable considering the benefits received".

Table 42: Responses concerning respondents' support for the current government and their attitudes towards the statement: "The amount of tax I have to pay is reasonable considering the benefits received".

Table 43: Responses concerning respondents' views about the future of South Africa and their attitudes towards the statement: "The amount of tax I have to pay is reasonable considering the benefits received" 
Table 44: Responses of population groups regarding the statement: "The government does not provide enough information about how they use taxpayers' money"...156

Table 45: Responses of language groups regarding the statement: "The government does not provide enough information about how they use taxpayers' money"...157

Table 46: Responses concerning respondents' support for the current government and their attitudes towards the statement: "The government does not provide enough information about how they use taxpayers' money"

Table 47: Responses concerning respondents' views about the future of South Africa and their attitudes towards the statement: "The government does not provide enough information about how they use taxpayers' money"

Table 48: Percentage of respondents who agree, disagree or have no opinion regarding statements relating to tax evasion.

Table 49: Relationship between respondents' demographic, economic or other factors and their attitudes towards tax evasion and tax compliance

Table 50: Relationship between respondents' views on specific tax-related statements and their attitudes towards tax evasion and tax compliance

Table 51: Relationship between respondents' perceptions regarding the statement: "A large proportion of taxes is used by the government for meaningless purposes" and their attitudes towards tax evasion.

Table 52: Relationship between respondents' perceptions regarding the statement: "The income tax rate (\%) should be the same regardless of the amount of income earned (i.e. everybody pays income tax using the same percentage irrespective of the amount you earn)" and their attitudes towards tax evasion...173

Table 53: Relationship between respondents' perceptions regarding the statement: "I do not know why I have to pay tax" and their attitudes towards tax evasion

Table 54: Relationship between respondents' perceptions regarding to the statement: "Tax is very complicated - I do not know how to calculate my own tax liability" and their attitudes towards tax evasion

Table 55: Relationship between respondents' perceptions regarding the statement: "The amount of tax I have to pay is reasonable considering the benefits received" and their attitudes towards tax evasion.....

Table 56: Relationship between respondents' perceptions regarding the statement: "The government does not provide enough information about how they use taxpayers' money" and their attitudes towards tax evasion 
Table 57: Percentage of respondents that responded positively with regard to general tax compliance statements.

Table 58: Relationship between respondents' perceptions regarding the statement: " $\mathrm{A}$ large proportion of taxes is used by the government for meaningless purposes" and their attitudes towards tax compliance 184

Table 59: Relationship between respondents' perceptions regarding the statement: "It is unfair to pay tax" and their attitudes towards tax compliance.

Table 60: Relationship between respondents' perceptions regarding the statement: "Income tax rates must be reduced" and their attitudes towards tax compliance......

Table 61: Relationship between respondents' perceptions regarding the statement: "The VAT rate must be reduced" and their attitudes towards tax compliance

Table 62: Relationship between respondents' perceptions regarding the statement: "The income tax rate (\%) should be the same regardless of the amount of income earned (i.e. everybody pays income tax using the same percentage irrespective of the amount you earn)" and their attitudes towards tax compliance.

Table 63: Relationship between respondents' perceptions regarding the statement: "Rich people should pay tax at a higher rate" and their attitudes towards tax compliance.

Table 64: Relationship between respondents' perceptions regarding the statement: 'Tax is very complicated - I do not know how to calculate my own tax liability" and their attitudes towards tax compliance

Table 65: Relationship between the respondents' perceptions regarding the statement: "The amount of tax I have to pay is reasonable considering the benefits received" and their attitudes towards tax compliance.

Table 66: Relationship between respondents' perceptions regarding the statement: "The government does not provide enough information about how they use taxpayers' money" and their attitudes towards tax compliance

Table 67: Relationship between respondents' attitudes regarding specific tax evasion statements and their attitudes towards tax compliance.

Table 68: Relationship between respondents' perceptions regarding the statement: "Government receives enough tax so it does not matter if some people evade tax" and their attitudes towards tax compliance 
Table 69: Relationship between respondents' perceptions regarding the statement: "The burden of tax is so heavy that many people are forced to evade it in order to survive" and their attitudes towards tax compliance

Table 70: Relationship between respondents' perceptions regarding the statement: "Since so many other people are evading tax, I cannot be blamed for evading tax" and their attitudes towards tax compliance

Table 71: Relationship between respondents' perceptions regarding the statement: "I work hard for the income I receive so I should be allowed to keep it all for myself" and their attitudes towards tax compliance

Table 72: Relationship between respondents' perceptions regarding the statement: "Wealthy people evade tax more often than poor people" and their attitudes towards tax compliance

Table 73: Crimes and appropriate penalties as indicated by the respondents..... 200

Table 74: Relationship between respondents' attitudes towards the severity of punishment for tax evasion and their attitudes towards tax evasion and tax compliance.

Table 75: Relationship between respondents' views regarding the severity of penalties for tax evasion and their attitudes towards tax evasion

Table 76: Relationship between respondents' perceptions regarding the statement: "People evade tax because the risk that the authorities find out is low" and their attitudes towards tax compliance

Table 77: Summary of relationship between respondents' demographic, economic or other factors and their attitudes towards tax-related statements

Table 78: Number of statements where respondents' attitudes were influenced by a specific demographic, economic or other factor

Table 79: Respondents' perceptions regarding specific tax-related statements and their attitudes towards tax evasion and tax compliance

Table 80: Relationship between respondents' attitudes towards a specific tax evasion statement and their attitudes towards tax compliance.

Table 81: Findings from the current study and findings from past research in relation to individual demographic, economic or other factors influencing respondents' attitudes towards general tax-related issues 
Table 82: Findings of current study and findings of past research in relation to respondents' individual demographic, economic or other factors and their attitudes towards tax evasion

Table 83: Findings of current study and findings of past research considering the relationship between respondents' perceptions towards specific tax-related statements and tax evasion

Table 84: Findings of current study and findings of past research in relation to respondents' individual demographic, economic or other factors and their attitudes towards tax compliance

Table 85: Findings of present study and findings of past research concerning the relationship between respondents' perceptions regarding specific tax-related statements and their attitudes towards tax compliance.

Table 86: Findings of the current and findings of past research and the relationship between respondents' perceptions regarding specific tax evasion statements and their attitudes towards tax compliance 


\section{LIST OF ABBREVIATIONS}

CGT:

COSATU:

GDP:

GLM procedure:

GST:

IRS:

JSE:

Lotto:

MarkData:

OECD:

RDP:

SAICA:

SARS:

SAS:

SITE:

VAT:
Capital Gains Tax

Congress of South African Trade Unions

Gross Domestic Product

General linear model procedure

General Sales Tax

Internal Revenue Service

Johannesburg Stock Exchange

National Lottery

MarkData Pty (Ltd)

Organisation for Economic Cooperation

Reconstruction and Development Programme

South African Institute for Chartered Accountants

South African Revenue Services

Statistical Analysis Software

Standard Income Tax on Employees

Value-Added Tax 